Litinfinite Journal

ISSN: 2582-0400 [Online]

CODEN: LITIBR

Vol-1, Issue-1 ( $\left.2^{\text {nd }} J u l y, 2019\right)$

Page No: $1-7$

DOI: 10.47365/litinfinite.1.1.2019.1-7

Section: Article

\title{
Connecting the Literature of Children and Adult: Socio-Political Commentary in Fantasy Tales like The Little Prince and Animal Farm
}

\author{
Dr. Paromita Mukherjee \\ Ph.D. in English Literature - University of Florida (USA) \\ M.A. in English Rhetoric and Professional Communication -New Mexico State University (USA) \\ Assistant Professor of English \\ Head of the Institution \\ Amity Institute of English Studies and Research \\ Amity University, Kolkata, India \\ Email Id: pmukherjee@kol.amity.edu
}

\begin{abstract}
Genres of fantasy tales, inclusive of allegories, animal fables and fairy tales can provide cutting insight and clarity about the complexities of society and the intricacies of human nature. These fantasy tales may have both literal as well as symbolic meanings. However, the characters here are often animals and plants that can talk and behave like human beings. This genre of storytelling exists in virtually every culture of the world. These stories have elements of fantasy and magic that are appealing to children. However, while the magical elements in traditional fairy tales are used for the purpose of creating delight and suspense in the imaginative minds of children, other types of fantasy tales can typically have a symbolic meaning attached to them. As a result, we find the terms allegories, fables and fairy tales used quite interchangeably while talking about fantasy tales.
\end{abstract}

Keyword: Fairy Tales, Fantasy Tales, Symbols, Magic Realism, Socio-Politics

Genres of fantasy tales, inclusive of allegories, animal fables and fairy tales, can provide cutting insight and clarity about the complexities of society and the intricacies of human nature. These fantasy tales may have both literal as well as symbolic meanings. However, the characters here are often animals and plants that can talk and behave like human beings. This genre of storytelling exists in virtually every culture of the world. These stories have elements of fantasy and magic that are appealing to children. However, while the magical elements in traditional fairy tales are used for the purpose of creating delight and suspense in the imaginative minds of children, other types of fantasy tales can typically have a symbolic meaning attached to them. As a result, we find the terms allegories, fables and fairy tales used quite interchangeably while talking about fantasy tales. Nevertheless, this genre of story telling is quite popular and equally appealing to both children and adults, who interpret them according to their social context, sensibility, and frame of reference. This type of writing has been used effectively as tools of social and political inquiry by authors of various countries. The Little Prince, published in 1943, written by the French author Antoine De Saint-Exupery is a thought provoking allegory of the human condition, which describes the intergalactic travel of a little boy in search of knowledge. Animal Farm, published in 
1946, written by the British author George Orwell, is a savage comedy on social injustice and political oppression, which describes how the animals of a farm revolt against the tyranny by humans and take control of the farm, but ultimately they end up with totalitarianism just as terrible. Written during the period of the Second World War, both the works can be interpreted in light of the prevailing political idealism and social condition of the time. Both the works have a timeless appeal to children and adults, since they present a transcription of a view of life through highly simplified symbols under the veneer of wit and humor. The objective of this paper is to investigate why fantasy tales like The Little Prince and Animal Farm are effective tools for social and political inquest and what kind of insights, they provide.

Fantasy tales became important tools for socio-political commentary in the twentieth century, due to various reasons. Firstly, with the rise of fascist and communist states across the world and the resultant censorship on free speech and criticism, social and political allegories were the only means of self-expression in many countries. The writers of these stories could often claim that their works were mere fantasies and thus escape the wrath of the state censors. A large number of texts were written in the style of animal fables. This is because, by setting human problems in the animal kingdom, a writer can achieve the distance necessary to objectively analyze the absurdity of human behavior. The animal kingdom is a neutral territory, without any distinctions based on class, race or religion, where we ascribe the virtues of honesty and innocence to all animals. If the story of the Animal Farm had been told in a human context, then we may not have felt the same sympathies for the oppressed animals. We might have been able to justify such behavior on the basis of our implicit biases and prejudices. Similarly, in the Little Prince, the love and loyalty of little boy towards the flower on his planet, touches us deeply and helps us to comprehend the message of the author. However, if the object of affection of the little prince had been a little girl from the Orient, would the story have elicited similar reactions of concern? Maybe racial prejudices would have coloured the emotions of the readers to some extent. Secondly, the use of animal representation helps us to visualize and relate to the characters in the story. This makes the underlying message easier to understand, and also makes it universal in scope. For instance, in the Animal Farm, we find it easier to associate the pigs to vices like greed and viciousness, and therefore we are not surprised when they try to distort the ideologies of the farm for their own selfish benefit. In The Little Prince, we can easily relate to the beauty of the rose, the cleverness of the fox and the mystery of the snake. As a result we become more engrossed in the story.

Both the tales have a universal and timeless appeal. The symbolic meaning associated with the characters in the stories, does not change with time. If these stories are told in a human context, they may become categorized as the literature of a specific period, with its own set of issues and interpretations, and as a result the message in these stories may have been ignored or lost. In the context of the Animal Farm, it is easy to see that, if the story was not based on the animal kingdom, it may have been regarded as another piece of political thought on 
communism and thereby relegated to the background. Similarly, if the Little Prince was to be written purely in the human context, it may have been considered as just another love story during the Second World War. It can be argued, therefore, that these kind of fantasy tales, by deriving from the genre of allegories, animal fables and fairy tales, provide objective, simple, universal and timeless interpretations of the social and political sphere in a language that is gentle, inviting and yet forceful.

At the literal level, the Little Prince is very engaging to children. The perspective of a small boy, as well as the elements of fantasy such as space travel and talking plants and animals, appeal to the imaginative faculty of children. Also, the various drawings of the author make the story visually alluring to children. According to John Harris: "the first chapter's unforgettable vignette about a much misunderstood drawing from the author's boyhood (a boa constrictor digesting an elephant which adults mistook for a hat) are plainly, delightfully intended to win over children"(183). In the first chapter the narrator also writes "Grown-ups never understand anything by themselves and it is rather tedious for children to have to explain things to them time and again" (The Little Prince 11). This perspective of the narrator towards the inability of adults to grasp simple things repeats itself throughout the novel and endears him to the children. However, there is a deep symbolical meaning attached to the adventures of the Little Prince, which has a timeless appeal to the grown-ups. The intergalactic travel of the Little Prince exposes that our society has become enmeshed in the trappings of money, power, vanity and intolerance, which prevents us from appreciating the value of friendship and love. When the Little Prince embarks on his journey, he comes across a businessman who was so busy with his calculations that he does not even look up and greet the Little Prince. He claimed that he owned the stars since he was the first person to think of this. He says: "I manage them, I count them and recount them. I am a man concerned with matters of consequence" (The Little Prince 55). This is an extremely thought-provoking allegory of the modern society. We engage in selfish activities and become so self-obsessed with our copyright laws and property rights that we do not observe the common civilities of welcoming people in our presence and listen to their adventures.

When the Little Prince visits the Earth, he is very surprised to find that people are constantly traveling from one place to another in express trains. When he asks the railway signalman why the people in the train were in such a hurry, the signalman replied: "No one is ever satisfied where he is" (The Little Prince 85). It is pertinent to explore the reason behind our dissatisfaction. Is it because the mass media in our consumerist society projects the grand illusions of materialistic comfort and coerces us to pursue monetary gains? Or is it because, somewhere along the way to adult hood, we have lost the innocence and natural curiosity of children, which used to enable us to find happiness and comfort in a small rag doll? The Little Prince also meets a merchant on the Earth, who wants to sell him a pill, which will quench a person's thirst for one whole week. This reflects that in the modern society we take 
recourse to artificial means in our daily life in order to save time. We take drugs that will reduce our weight when we know that a jog around the park is a far healthier option. We send forwarded emails and messages to our friends and relatives instead of taking the time to write a few lines, ourselves. In the Little Prince, Saint-Exupéry tells us that fast artificial solutions do not really make us happy. It is the effort that we put into our endeavors that makes the result sweet and memorable.

Our impatience and dissatisfaction also affects us in our relationships. When the Little Prince met the fox, the fox said, "Men have no more time to understand anything. They buy readymade things in the shops. But since there are no shops where you can buy friends, men no longer have friends" (The Little Prince 79). According to Saint-Exupery, we no longer have the time to go through the rites and rituals of friendship. We do not wish to know our friends' anxieties, their aspirations, and their greatest concerns. We live in a world where statistics and material things have become more important than human relationships. When the Little Prince realizes that the rose he left behind in his planet is unique because of the time and affection he had lavished on her, the fox tells him another secret: "It is only with the heart that one can see clearly. What is essential is invisible to the eye...Men have forgotten this basic truth. But you must not forget it. For what you have tamed you become responsible for ever" (The Little Prince 82). This is the central idea of the novel and is a crystallization of Saint-Exupery's philosophy of life. As a result, it may sound moralizing, but we cannot ignore its persuasiveness.

In the Animal Farm, the animals overthrow their human oppressors by rebellion. At first the farm prospers but soon the pigs take control of the farm and start distorting the ideologies of the farm for their personal gains. Eventually, the seven principles of Animalism become reduced to a single principle reading, 'all animals are equal, but some animals are more equal than others.' At a literal level, Animal Farm can be seen as a children's story about an animal rebellion on a farm. The plain language, straightforward plot, one-dimensional animal characters give the appearance of a simple and interesting animal fable. The work shows, how corrupt animals gain power through manipulation, and invites the young readers to respond to the sufferings of the poor animals in the farm. In fact, Orwell explained that a scene of a suffering horse, which later became the model for Boxer, inspired him to conceive Animal Farm. According to John Rodden, one of Orwell's friends had reported: "my young son insisted on my reading it chapter by chapter.... and he enjoys it innocently as much as I enjoy it maliciously"(xvii).

However, beyond the literal level, the Animal Farm is a historical satire and vicious critique of the Russian Revolution and the subsequent Soviet dictatorship. In fact, it is a political treatise that suggests larger lessons about power, tyranny and revolution. This is not merely limited to the Soviet Union, but equally applicable to all nations - past present and future, and 
all forms of totalitarianism - capitalist, socialist, fascist or communist. Indeed, with the collapse of the Berlin Wall in 1989 and the dismantling of the Soviet Union in 1991, one might argue that Orwell's novel has lost its relevance. However, that is far from true. The Animal Farm exposes how tyrants rise to power on the back of ideologies of liberation and equality, and then distort those ideologies with the use of propaganda and political rhetoric to justify their own selfish, unprincipled actions. It is a testament to Orwell's acute political intelligence and to the universality of his fable that the pig leader Napoleon can easily stand for any of the great dictators and political schemers in world history, even those who arose after Animal Farm was written.

The use of political rhetoric and propaganda has been one of the most outrageous ways in which the pigs distorted the original ideologies of Animalism and manipulated the other animals in the farm. Once the animals had driven out Mr. Jones in the battle of the cowshed, they realized that the milk and apples in the farm were being secretly consumed by the pigs. Squealer, who is Napoleon's propagandist, justifies this by saying: "It is for your sake that we drink that milk and eat those apples. Do you know what would happen if we pigs failed in our duty? Jones would come back! Surely comrades, there is no one among you who wants to see Jones come back?" (Animal Farm 52). As a result, the other animals were unable to oppose the pigs without also opposing the ideals of the Rebellion. Throughout the novel the pigs justify their own unprincipled actions - to participate in trade, to sleep on beds, to kill other animals, to drink wine. They distort the principles of Animalism to suit their actions, and portray any dissent as being contrary to the spirit of the Rebellion. This is a strategy that has been followed by dictators throughout the world for accumulating wealth and consolidating their power.

After Snowball was chased off from the farm by the attack dogs, Napoleon expanded his powers considerably. He forbade any further political debates in the farm and established himself as the sole decision maker, which was again justified by the eloquent rhetoric of Squealer, who says: "I trust every animal here appreciates the sacrifice that Comrade Napoleon has made in taking this extra labour upon himself. Do not imagine, comrades, that leadership is a pleasure! On the contrary it is a deep and heavy responsibility" (Animal Farm 69). A similar strategy was adopted by Hitler when he had risen to power on the basis of democratic elections and shortly afterwards banned all opposing parties and future elections. Stalin pursued a similar policy in the Soviet Union when he exercised unilateral powers by distorting Marx's theories of Communism.

When the windmill, constructed by the hard labour of the animals in the farm, collapsed due to faulty design, Napoleon very cleverly blamed Snowball for it, and thereby generated great negative unity among the animals. Governments throughout the world have long enhanced their importance and popularity by alluding to the horrors of an invisible enemy, compared to which their own misdeeds or incompetence seem acceptable. Stalin used this tactic in Russia by first, evoking a demonized notion of Trotsky, and then killing or imprisoning the dissenters in his party by accusing them of sympathizing with Trotsky. Hitler used it to galvanize the entire German nation against the Jews. Even few years back, we saw the 
Litinfinite Journal

ISSN: 2582-0400 [Online]

CODEN: LITIBR

Vol-1, Issue-1 ( $\left.2^{\text {nd }} J u l y, 2019\right)$

Page No: $1-7$

DOI: 10.47365/litinfinite.1.1.2019.1-7

Section: Article

President of America using the invisible omnipresent threat of terrorists to invade Iraq only perhaps to serve the purpose of the multinational organizations that stand to gain from that war.

In the Animal Farm, political rhetoric went hand-in-hand with propaganda showing that production had increased and everybody was better off, although in reality the conditions of the animals were far worse than ever before. Napoleon took the credit for every successful achievement and every stroke of good fortune. One could often hear the hens in the animal farm remarking "Under the guidance of our leader, Comrade Napoleon, I have laid five eggs in six days" (Animal Farm 100). As we all know, such propaganda is extremely common in all countries of the world during election time. In the end, the pigs in the Animal Farm were walking on their hind legs, carrying whips in their trotters and it became impossible for the rest of the animals to distinguish pigs from humans. Napoleon and the other pigs became identical to the human farmers, just as Stalin and the Russian communists eventually became indistinguishable from the aristocrats whom they had replaced and the Western capitalists whom they had denounced. It is indeed a terrifying thought of our times that, in the search for terrorists, the great democratic nations of the world may start adopting the same ideology and the same means as the terrorists themselves, and finally come to resemble them in their thoughts and deeds.

The analysis of these two novels reveals that these kind of fantasy tales represent a segment of literature where children and adults intersect. While children love the fantastic tales written in the tradition of animal fables, adults enjoy the symbolic meanings of the stories and the underlying humor. Strangely though, there are not many notable texts of this genre in the latter half of the twentieth century. Some contemporary authors who come to mind are: Richard Parks, Neil Gaiman, and Jennifer Rowe. Their stories represent new-millennium characters with their modern dilemmas, and are profoundly and wittily supported by a cast of frogs, princes, witches and dragons. However, a lot of the writings that pass of as fantasy tales these days, appear to be quite unimaginative and uninspired. There seems to be a greater emphasis on creating weird characters and complicated plots, and less emphasis on the subtle humor and universal messages that were found in the earlier texts. Paradoxically, what should be the most imaginative form of literature has become one of the most predictable. 
Litinfinite Journal

ISSN: 2582-0400 [Online]

CODEN: LITIBR

Vol-1, Issue-1 ( $2^{\text {nd }}$ July, 2019)

Page No: 1-7

DOI: 10.47365/litinfinite.1.1.2019.1-7

Section: Article

Works cited:

i. Breaux, Adele. Saint-Exupery in America, 1942-1943: A Memoir. Rutherford: Fairleigh Dickinson University Press, 1971.

ii. Calder, Jenni. Animal Farm and Nineteen Eighty-Four. Philadelphia: Open University Press, 1987.

iii. Capestany, Edward J. The Dialectic of the Little Prince. Washington D.C.: University Press of America, 1982.

iv. Carey, John. Ed. George Orwell Essays. New York: Everyman Library, 2002.

v. Harris, John. Chaos, Cosmos, and Saint-Exupery's Pilot Hero: A Study in Mythopoeia. Scranton: University of Scranton Press, 1999.

vi. $\quad$ Orwell, George. Animal Farm: A Fairy Story. New York: Signet Classic, 1996.

vii. $\quad$ Robinson, Joy D. Antoine de Saint-Exupery. Boston: Twayne Publishers, 1984.

viii. Rodden, John. Ed. Understanding Animal Farm: A Student Casebook to issues, sources, and historical documents. Connecticut: Greenwood Press, 1999.

ix. $\quad$ Saint-Exupery, Antoine De. Wartime Writings 1939-1944. New York: Harcourt Brace, 1982.

x. Saint-Exupery, Antoine De. The Little Prince. Hertfordshire, UK: Wordsworth Classics, 1995.

xi. $\quad$ Smyer, Richard I. Animal Farm: Pastoralism and Politics. Boston: Twayne Publishers, 1988.

xii. Webster, Paul. Antoine de Saint-Exupery: The Life and Death of the Little Prince. London: Macmillan, 1993. 